\title{
面内せん断力を受ける波形鋼板パネルの端部崩壊挙動に関する研究 A STUDY ON END FAILURES IN CORRUGATED STEEL SHEAR DIAPHRAGMS
}

\author{
清 水 信 孝*, 五十嵐規矩夫** \\ Nobutaka SHIMIZU and Kikuo IKARASHI
}

\begin{abstract}
Tests on shear corrugated steel plates were carried out to examine effect of shape and thickness of cross section on end failure action that may occur at the ends of flutes in shear diaphragms. Based on the test result and observation obtained through this research, previous deformation model for stiffness estimation were reviewed, and the deformation model were developed into strength model with application of yield line hinge. Strength design formulas were derived from the strength model using a limit analysis technique. Comparison with the test results showed that the derived formulas provided appropriate stiffness and strength estimation.
\end{abstract}

Keywords : Corrugated steel plate, Shear stiffness, Shear strength, Elastic strain energy, Plastic strain energy 波形鋼板, せん断岡性, せん断耐力, 弾性ひずみエネルギー, 塑性ひずみエネルギー

\section{1. はじめに}

波形鋼板は主に積雪や風圧による面外力に抵抗する材として建築 構造物の屋根や壁として利用されているが，面内せん断力（図 1 (a) ) に対する抵抗特性を有効活用した構法も試みられている。欧米では 1960 年代の先駆的な Ni1son の実験的な研究 ${ }^{7}$ を契機にDiaphragm $\operatorname{Design}^{8 \sim 10)}$ と称される設計手法が確立され，屋根鋼板へ適用するこ とで水平ブレースを省略した設計などが可能となっている．国内で も 1970 年代初めに床鋼板を単体で耐力壁に適用する基本的な考え方 が設計施工規淮 ${ }^{19)}$ に示され，近年では，土木分野の波形鋼板ウェブ PC 橋の設計技術 ${ }^{12}$ を建築構造の耐震壁に応用寸る研究 ${ }^{33,4)}$, 産学協 同による波形鋼板を組み込んだ積層型鋼パネル構造の開発・探求 ${ }^{5}$ が進められるなど，面内せん断力に抵抗する構造材料としての発展 が波形鋼板に期待されている.

このような発展に向け，波形鋼板のせん断抵抗特性を十分に解明 する必要があると考え，筆者等はせん断座屈挙動に着目し，波形形 状が全体座屈と局部座屈の連成に与える影響, 周辺支持辺数や固定 度が座屈耐力に与える影響、の定量評価を試みた ${ }^{6}$. 一一方, 座屈耐力 を高めた波形鋼板では, 全体座屈や板要素の局部座屈より先行して 図 1(b) および図 1(c) に示すような波形鋼板の山部が長手方向の端 部で崩壊するモードが生じ得ることが知られているが ${ }^{12)}$, この挙動

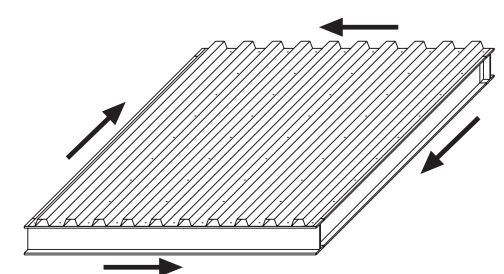

(a) 波形鋼板パネル

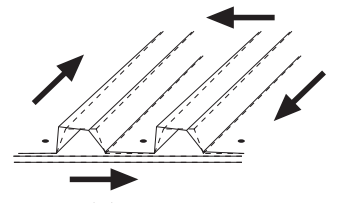

(b) スウェイ

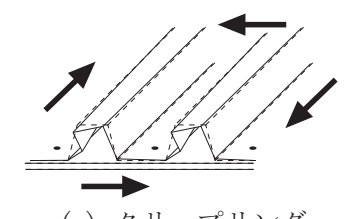

(c) クリップリング
図 1 面内せん断力を受ける波形鋼板パネルの端部崩壊挙動

は十分に明らかにされているとは言い難い。この端部崩壊に対する 耐力式としては, Davies の研究 ${ }^{12)}$ に基づく評価式が一部の設計指針 9)に採用されている.この評価式は, 実際の構造物に適用されてい る鋼板屋根の仕様を主な対象とした面内せん断性試験で確認された, (1)断面が倒れこむ崩壊モード (図 1(b) スウェイ), (2)ウェブ局所圧 壊（図 1(c) クリップリング), による 2 つの異なる破壊形態で決定 された実験耐力を, 最終的にはスウェイの崩壊モードに基づき導出
* 新日本製鐵鋼構造研究開発センター 主任研究員・工修 東京工業大学大学院理工学研究科建築学専攻 博士後期課程 (社会人コース)

** 東京工業大学大学院理工学研究科建築学専攻 准教授・博士 (工学)
Senior Researcher, Steel Structure Development Center, Nippon Steel, M. Eng. Graduate Student, Dept. of Arch. and Building Eng., Tokyo Institute of Technology Assoc. Prof., Dept. of Arch. and Building Eng., Tokyo Institute of Technology, Dr. Eng. 
された耐力式で一義的に評価するというものである. しかしながら， 実験結果で主に観察された崩壊モードと耐力式の導出で仮定する崩 壞モードに不一致が見られる, さらに耐力式導出の基䃈とするスウ エイの崩壊モードにおける三次元的な変形が十分に考慮されていな い, これらが一因となり著しく安全側の評価を与える傾向にある, といった課題を残す.

本研究では, 波形鋼板パネルの端部崩壊挙動として特に断面が倒 れこむスウェイの崩壊モードに対する耐力評価に焦点を当て, 断面 形状や板厚が与える影響を面内せん断試験により確認するとともに, 実験観察された破壊形態を参考に三次元的な変形を考慮した塑性崩 壊モデルを仮定し, 極限解析の適用により耐力式の提案を試みた. この塑性崩壊モデルは，波形鋼板パネルのせん断剛性評価で仮定す る弾性変形モデル ${ }^{14)}$ を拡張することで求めたものであり, ここでは, せん断剛性式の導出を改めて示すとともに本試験への適用性の検証 も行なう.

\section{2. 波形鋼板パネルの端部崩壊挙動に関する既往の耐力式}

Davies ${ }^{12)}$ は, 図 2 に示す波形鋼板の板厚 $t$ に対寸る山高さ $h$ の比 $h / t$ が $25 \sim 160$, 山ピッチ $q$ に対する $h$ の比が $h / q$ が 0.15 から 0.7 の断面形状を対象に，波形鋼板の下フランジの一部を枠にビス等で 接合したディテールを用い，実用仕様のより幅広い範囲に対する性 能確認試験を参考として耐力式を提案している．ここでは, 断面が 倒れこむスウェイ (図 1(b)), ウェブが局所圧壊するクリップリン グ (図 1 (c)) , 波形鋼板と枠の接合部の破壊，それぞれの崩壊モー ドに対する耐力式の導出が試みられている，接合部を除く前者二つ の破壊形態に関しては, 最終的にはスウェイの崩壊モードに基づく 耐力式により両者を安全側に評価できると考えられている.

スウェイの耐力式は, 図 3 (a) に示寸ような面内せん断力 ${ }_{c} P_{0}$ を受 ける長さ $b$ の波形鋼板の山部長手方向における端部の微小幅部分の 挙動に着目し, 図 3(c) の崩壊機構がな寸内部仕事 $u_{i}$ と, 図 $3(\mathrm{~b})$ に 示寸分布の弾性曲げモーメントを起こす外力がなす外部仕事 $u_{e}$ の釣 合から導かれる. なお, $u_{e}$ の算出では $\mathrm{A}$ 点の支持条件をピンと仮定(図 3 (b) の $\left.m_{\mathrm{A}}=0\right)$ するのに対し, $u_{i}$ の算出では図 3 (c) の崩壊機構に示 すように $\mathrm{A}$ 点に曲げヒンジの発生を想定しており，支持条件の扱い に曖昧な点が見られる.

内部仕事 $u_{i}$ は山部長手方向に対する単位幅当たりの全塑性モーメ ント $m_{\mathrm{p}}$ と曲げ降伏ヒンジの回転角 $\theta_{1}$ および $\theta_{2}$, 各断面寸法を用いて 次式で与えられる.

$u_{i}=m_{p}\left(2 \theta_{1}+2 \theta_{2}\right)=2 m_{p}(q-e) / e \cdot \theta_{1}$ . . . (

なお， $m_{\mathrm{p}}$ は板厚 $t$ と素材降伏点 $\sigma_{y}$ を用いて次式で表される.

$m_{p}=t^{2} \cdot \sigma_{y} / 4$

.................. (2)

外部仕事 $u_{e}$ は単位外力がな寸節点 $\mathrm{B}$ および節点 $\mathrm{E}$ の単位幅当たりの 曲げモーメント $m_{\mathrm{B}}$ および $m_{\mathrm{E}}$ と節点の回転角 $\theta_{1}$ および $\theta_{2}$ を用い，外 力の大きさ $P_{0}$ を乗じたかたちで次式で与えられる.

$$
u_{e}={ }_{C} P_{0}\left\{m_{B}\left(\theta_{1}+\theta_{2}\right)+m_{E} \cdot \theta_{1}\right\}={ }_{C} P_{0}\left\{m_{B}(q-e)+m_{E} \cdot e\right\} e \cdot \theta_{1} \quad \cdots(3)
$$

内部仕事 $u_{i}$ と外部仕事 $u_{e}$ の釣合から端部崩壊耐力 ${ }_{C} P_{0}$ を式 (4) とし て得る.ここで， $k_{m}$ は波形鋼板のゆがみ抵抗を表す值であり，形状 と弾性曲げモーメントを用いて式（5）で表される.

$$
{ }_{c} P_{0}=k_{m} \cdot \sigma_{y} \cdot t^{1.5} \cdot b / q^{0.5} \quad \ldots \ldots \ldots \text { (4) }
$$

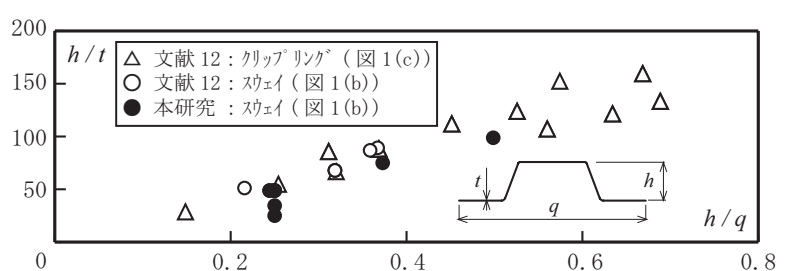

図 2 既往試験 ${ }^{12)}$ におけるパネル形状と崩壊モード

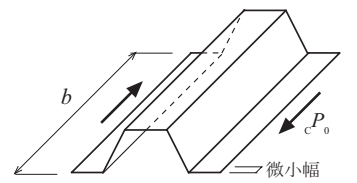

(a) 面内せん断力

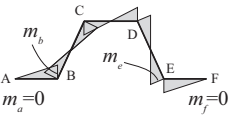

(b) 曲げモーメント

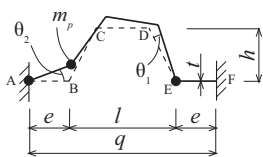

(c) 崩壊機構
図 3 既往研究 ${ }^{12}$ で仮定する崩壊機構

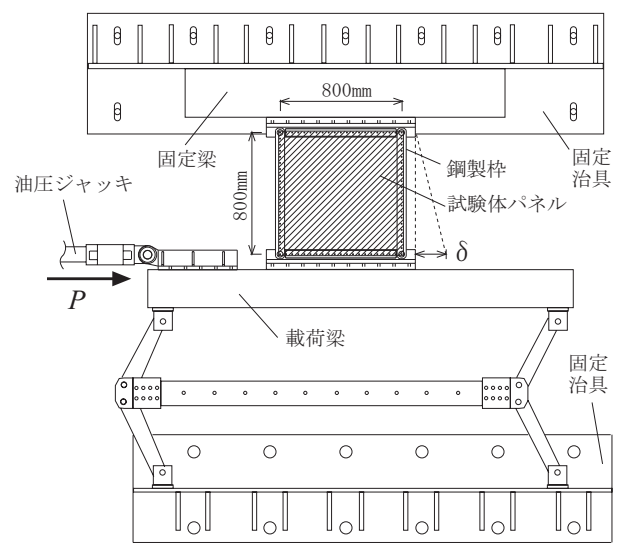

(a) 全体配置

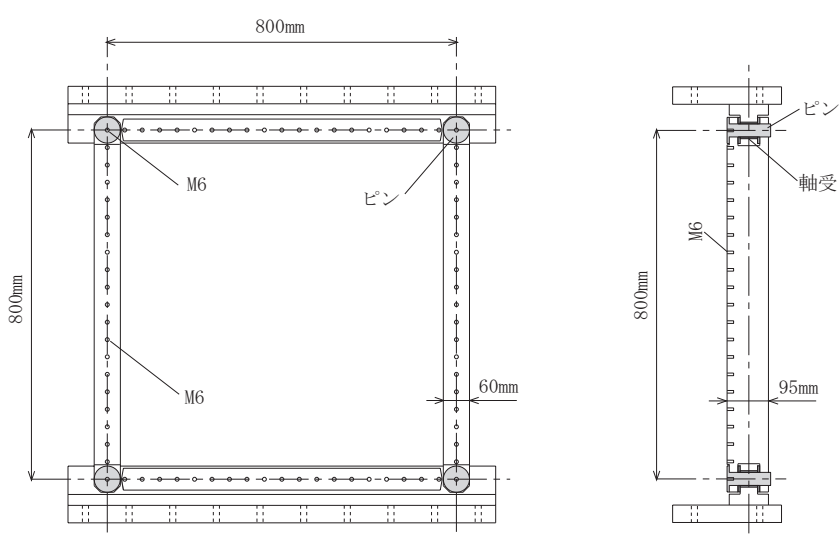

(b) 鋼製枠

図 4 試験装置

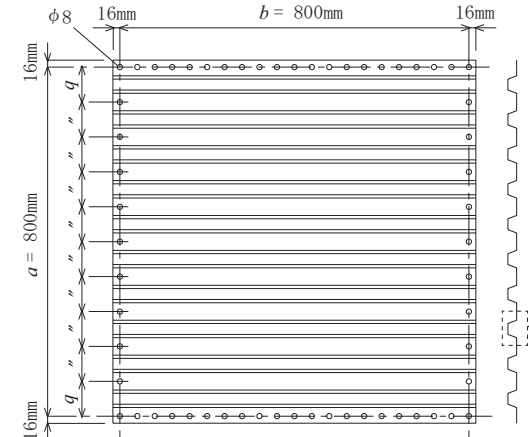

（a）全体寸法

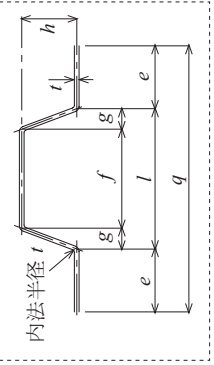

（b）断面形状寸法
図 5 試験体パネル 


$$
k_{m}=\frac{q^{0.5} \cdot t^{0.5}(q-e)}{2 b\left\{m_{B}(q-e)+m_{E} \cdot e\right\}}
$$$$
\text { ........ (5) }
$$

文献 12 では実験結果との比較検討から式 (4) の検証が試みられて いるが, 図 2 中の記号 $\triangle$ で示すウェブが局所圧壊するクリップリン グ（図 1(c)）を起こした試験結果が評価対象の大半を占めており, 記号○で示す断面が倒れこむスウェイの崩壊モード（図 1(b)）その ものの検証は十分に行われていない. また, 図 3 (c) に示す崩壊機構 は，端部位置での微小幅の挙動にしか焦点が当てられておらず，山 部の長手方向の変形挙動は十分に考慮されていない。このような因 子の影響もあり, 式 (4) は弾性限耐力を著しく安全側に評価する程 度の精度に留まっている. なお， $k_{m}$ は式 (5) で表されるが, 最終的 には実験係数として一義的に定められ，下フランジ毎に波形鋼板を 枠に接合した接合仕様を対象として, 文献 12 では $k_{m}=0.5$, 文献 9 で は $k_{m}=0.9$ の值が採用されている.

\section{3. 端部崩壊挙動の力学特性把握に向けたパネルせん断試験}

\section{1 せん断試験の概要}

波形鋼板パネルの断面形状と板厚および周辺接合条件が端部崩壊 挙動の力学特性に与える影響の確認に向け, 図 4 に示寸試験装置を 用いた面内せん断試験を行った。試験体となる波形鋼板パネルの下 フランジ面を, 図 4(b)に示す四隅にピン機構（自己潤滑タイプの 軸受を設置）を設けた鋼製枠（ピン間距離を $800 \mathrm{~mm} \times 800 \mathrm{~mm}$ ，枠断面 を幅 $60 \mathrm{~mm} \times$ 高さ $95 \mathrm{~mm}$ の無垢材とした）の上面にボルト接合し, 図 4 (a) に示すように鋼製枠の一辺を反力床に固定した固定梁に締結し, その対辺を載荷梁につなぎ，油圧ジャッキを用いて静的単調な面内 せん断力 $P$ を与え, せん断変形 $\delta$ を測定した。載荷は、最大耐力 に到達した後、破壊状況が明確になるまで行い，せん断変形角が約 $1 / 40$ となる $\delta=20 \mathrm{~mm}$ を超える付近での載荷終了を基本とした。端部 崩壊挙動による変形を確実に捉えるためにパネル周囲と鋼製枠の接 合部は先行降伏させないことを基本とし，パネルの下フランジ面と 鋼製枠は六角穴付きボルトM6（締め付けトルク $12 \mathrm{Nm}$ ）を用いた摩擦 接合とした。ボルト頭部とパネルの間には図 6 に示寸座金タイプの 接合金物を設け，摩擦接合面の面積を確保するとともに，接合金物 底面の長さ (径) $j$ を調整可能とし, 鋼製枠に対する下フランジの固 定幅を変化させた。

試験体パネルは，図 5 に示寸寸法記号で形状を設定し，板厚 0.4 〜 $0.8 \mathrm{~mm}$ の薄鋼板を折り曲げ半径（内法）が板厚と同等となるよう にプレス成形により製作した. 各記号は， $a$ : パネル幅， $b$ : パネル 長さ, $q$ : 山ピッチ, $h:$ 山高さ, $t$ : 板厚, $e:$ 下フランジ幅の $1 / 2$ ( $2 e$ が下フランジ幅に相当),$f$ : 上フランジ幅, $g$ : ウェブの投影幅, $l$ : 上フランジ幅とウェブ投影幅の和, を表す， パネル全体の寸法 $(a=b=800 \mathrm{~mm})$ および山ピッチ $(q=80 \mathrm{~mm})$ は各試験体で共通とし，端 部崩壞挙動の力学特性にパネルの断面形状, 板厚, 周辺接合条件が 与える影響を把握するため, 上フランジ幅 $f$, 山高さ $h$, 板厚 $t$, 接 合金物の長さ（径） $j$ を主要な実験変数に設定した。

実験変数の一覧を表 1 に示寸。試験体名称の記号は,「f」以下の 数值が上フランジ幅,「t」以下の数值が板厚, 「h」以下の数值が高 さを表す。また，末尾に「J」を付記したものは，図6(b)のように 下フランジの中央部のみを鋼製枠に固定した試験体を表し, 付記が ないものは図 6 (a) に示すように，下フランジ幅のほぼ全てを鋼製

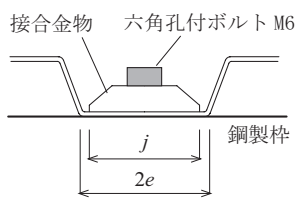

(a) 全幅固定

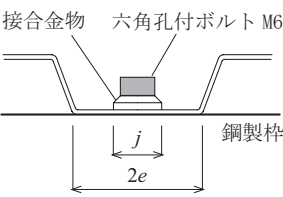

(b) 中央固定

図 6 パネルと枠の接合仕様

表 1 実験変数

\begin{tabular}{|c|c|c|c|c|c|c|c|c|c|c|c|c|}
\hline \multirow{2}{*}{\multicolumn{2}{|c|}{ 試験体 }} & \multicolumn{10}{|c|}{ パネル形状 } & \multirow{2}{*}{$\begin{array}{c}\text { 接合 } \\
j \\
(\mathrm{~mm})\end{array}$} \\
\hline & & $\begin{array}{c}a \\
(\mathrm{~mm})\end{array}$ & $\begin{array}{c}b \\
(\mathrm{~mm})\end{array}$ & $\begin{array}{c}t \\
(\mathrm{~mm})\end{array}$ & $\begin{array}{c}q \\
(\mathrm{~mm})\end{array}$ & $\begin{array}{c}f \\
(\mathrm{~mm})\end{array}$ & $\begin{array}{c}e \\
(\mathrm{~mm})\end{array}$ & $\begin{array}{c}g \\
(\mathrm{~mm})\end{array}$ & $\begin{array}{c}h \\
(\mathrm{~mm})\end{array}$ & $\begin{array}{c}l \\
(\mathrm{~mm})\end{array}$ & $\begin{array}{c}2 e \\
(\mathrm{~mm})\end{array}$ & \\
\hline & t04-h20-f40 & 800 & 800 & 0.4 & 80 & 40 & 20 & 0.0 & 20 & 40 & & 34 \\
\hline & & 300 & 80 & 0.4 & 80 & 25 & 20 & 7. & & & & \\
\hline & & 800 & 800 & 0.4 & 80 & 15 & 20 & 12.5 & 20 & 40 & & \\
\hline & & 800 & 800 & 0.4 & 80 & c & 20 & 20 & 2 & 40 & & \\
\hline & t04-h: & 800 & 80 & 0. & 80 & 25 & 20 & 7.5 & 30 & 40 & & \\
\hline & t04-h & 800 & 800 & 0.4 & 80 & 25 & 20 & 7.5 & 40 & 40 & 40 & \\
\hline & & 800 & 800 & 0.6 & 80 & 25 & 20 & 7.5 & 20 & 40 & & \\
\hline & t08-h20-f25 & 800 & 800 & 0.8 & 80 & 25 & 20 & 7.5 & 20 & 40 & 40 & \\
\hline & t04-h20-f32 & 800 & 800 & 0.4 & 80 & 31.6 & 15.8 & 8.4 & 19.6 & 48.4 & 31.6 & \\
\hline & t04-h20-f32J & 800 & 800 & 0.4 & 80 & 31.6 & 15.8 & 8.4 & 19.6 & 48.4 & 31.6 & 1 \\
\hline
\end{tabular}

表 2 鋼材の機械的性質

\begin{tabular}{|c|c|c|c|c|c|}
\hline \multicolumn{2}{|c|}{ 板厚 (mm) } & 降伏点 & 引張強さ & 破断伸び & 試験片 \\
\hline 規格 & 実測 & $\left(\mathrm{N} / \mathrm{mm}^{2}\right)$ & $\left(\mathrm{N} / \mathrm{mm}^{2}\right)$ & $(\%)$ & 規格 \\
\hline 0.4 & 0.41 & 267 & 366 & 37.9 & JIS5 \\
\hline 0.6 & 0.58 & 277 & 373 & 38.4 & JIS5 \\
\hline 0.8 & 0.77 & 251 & 353 & 41.2 & JIS5 \\
\hline
\end{tabular}

枠に固定したものを表す.シリーズ I は, 波形鋼板の断面形状の 影響を確認することを目的とし，下フランジ幅一定 $(2 e=40 \mathrm{~mm})$ で, $t=0.4 \mathrm{~mm}, f=25 \mathrm{~mm}, h=20 \mathrm{~mm}$ の試験体（t04-h20-f25）をパラメータの 基準とし，板厚 $t$ を $0.4 ， 0.6 ， 0.8 \mathrm{~mm}$ ，上フランジ幅 $f$ を $0 ， 15 ， 25$, $40 \mathrm{~mm}$, 高さ $h$ を $20,30,40 \mathrm{~mm}$ と変化させた. 下フランジと鋼製枠は, 幅 $12 \mathrm{~mm} \times$ 長さ $(j) 34 \mathrm{~mm}$ の角形の底面を持つ接合金物を介してボル 卜接合し，鋼製枠からの下フランジの浮き上りを抑制するものとし た．シリーズII は，鋼製枠に対する下フランジの固定幅の影響を確 認することを目的とし，パネル形状について, $t=0.4 \mathrm{~mm}, f=31.6 \mathrm{~mm}$, $2 e=31.6 \mathrm{~mm}, h=19.6 \mathrm{~mm}$ を共通とし, 接合金物底面の寸法を変化させた. t04-h20-f32 は，シリーズ I と同様に鋼製枠からの下フランジの浮 き上りを抑えたもので，幅 $12 \mathrm{~mm} \times$ 長さ $(j) 28 \mathrm{~mm}$ の底面を持つ接合 金物を用いている。一方， t04-h20-f32J は，下フランジの中央部の みを鋼製枠に固定する従来のデッキプレートやサイディングの接合 方法を意識したものであり，直径（j） $12 \mathrm{~mm}$ の円形底面を有する接合 金物を用い，下フランジの鋼製枠からの浮き上りを許容するものと した，各試験体とも凹凸のない平滑な辺については，円形底面の接 合金物を用いて $40 \mathrm{~mm}$ ピッチでパネルを鋼製枠にボルト接合した。試 験体パネルの製作に用いた鋼材は，シリーズ I および II に共通であ り，その機械的性質を表 2 に示す.

なお，パネルの断面形状は，全体座屈や局部座屈よりも端部崩壊 を先行させることを狙い設定したものであるが，パラメータの基準 （t04-h20-f25，t04-h20-f32）は，一般的なキーストンプレートの約 1/1.3，デッキプレートの約 1/3.5 のスケールに概ね対応している. 山ピッチに対する山高さの比 $h / q$ は $0.25 \sim 0.5$, 板厚に対する山高 
さの比 $h / t$ は $25 \sim 100$ であり, 既往研究 ${ }^{12)}$ における試験体との対応 を図 2 に示寸.

\section{2 パネル形状および接合条件が端部崩壊挙動に与える影響}

実験観察された端部崩壊の状況を写真 $1 \sim 2$ に, 各試験体のせん 断力 $P$ とせん断変形 $\delta$ の関係を図 8 に示す. 図 8 (a) 〜 (c) では実 験変数の影響を比較するため, シリーズ I で比較の基準とした t04h20-f25 を重複して記載してある. また, 図 7 に基づき定義した実 験值を表 3 に示寸。ここで, 初期剛性実験值 $K$ は $\delta=1 \mathrm{~mm}$ （せん断変 形角で $1 / 800$ に相当, 各試験体の線形域との対応をみながら便宜的 に定義）時の割線剛性, 最大耐力実験值 $P_{\text {max }}$ は実験で発揮された最 大耐力として定義した. また, 降伏耐力実験值 $P_{y}$ は, 最大耐力 $e_{e} P_{\text {max }}$ の点を通り変形軸に平行に引いた直線と初期剛性 $K_{e}$ を示す直線との 交点の変形に対応する荷重として定義した。 $e_{y}$ は, 床鋼板を用いた 耐力壁の面内せ几断力に対する降伏荷重が General Yield Method ${ }^{18)}$ により妥当に定まるという文献 19 の知見を参考に定義したものであ り, 図 8 に示寸各試験体の $P-\delta$ 関係において剛性低下が見られる荷 重域に概ね対応している.

実験観察された代表的な変形挙動として, t04-h20-f25 の状況を 写真 1 に示すが，断面を長方形および台形とした他の試験体でも同 様の挙動が観察されている. 載荷初期の線形域から写真 1 (a) に示 すパネル端部が倒れ込むように断面がゆがむ変形を示し，この変形 の進展に伴い徐々に剛性を低下しながら最大耐力 $P_{\text {max }}$ に到達すると いう性状，いわゆるスウェイの挙動が見られた。写真 1 (b) は写真 1 (a) と同じ最大耐力 $P_{\text {max }}$ の状況をパネル面に直交する方向から観察 したものであり, 山部はその稜線をほぼ線形に保ちながら, 長手方 向中央 $\left(A^{-}-A^{\prime}\right.$ 部) に対して両端の断面が逆対称に倒れこむ変形 (写 真下方が右側，写真上方が左側に傾倒）が見られる. 断面の変形は 山部の長手方向中央に近づくにつれ線形的に減少し, 中央位置 A-A' 部近傍では断面の変形はほとんど生じていない. 写真 1 (a), 1 (b) に示寸最大耐力 $P_{\text {max }}$ の状態からさらに載荷を進めると, スウェイの 崩壊モードの進展で断面が大きく倒れこみ, 耐力劣化を伴いながら 断面が倒れこむ側でウェブが局所的に折れ曲がるクリップリングの 崩壊モードに移行した。また, クリップリングの発生と同時期に下 フランジの板要素のせん断座屈が顕著となり, 最終的には鋼板と枠 をつなぐ接合部近傍の下フランジに局所的な張力場が形成される抵 抗機構へと移行した. この張力場の形成により, 最大耐力到達後の 耐力劣化は抑制され, ほとんどの試験体において $\delta=10 \sim 20 \mathrm{~mm}$ の変 形域で一定の耐力を維持するという荷重変形特性が見られた.

一方，断面を三角形とした t04-h20-f0 では，写真 2 に示すように 断面がゆがむ変形をほとんど生じないまま圧縮力を負担する側のウ

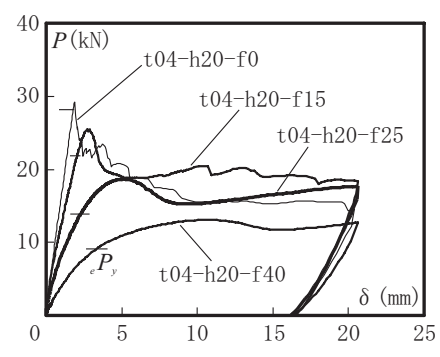

（a）上フランジ $f$ の影響

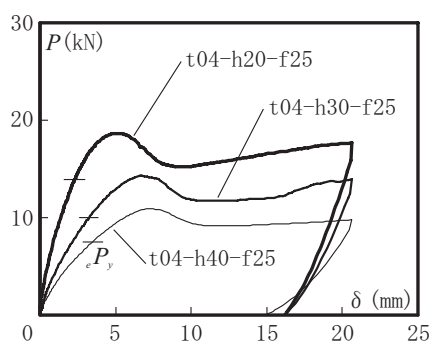

(b) 高さ $h$ の影響

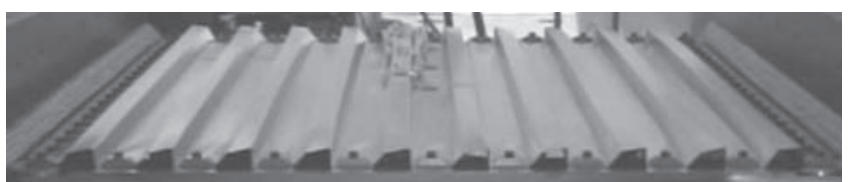

(a) 断面のゆがみ / 最大耐力 $e_{e \text { max }}$ 時

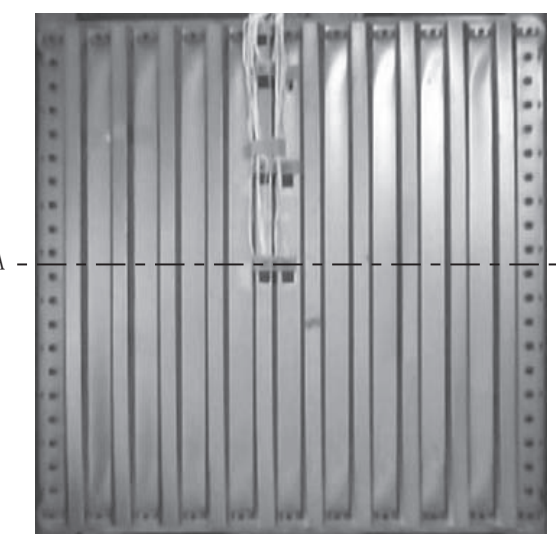

(b) 稯線の変形 / 最大耐力 $P_{\text {max }}$ 時

写真 1 実験観察（t04-h20-f25 試験体）

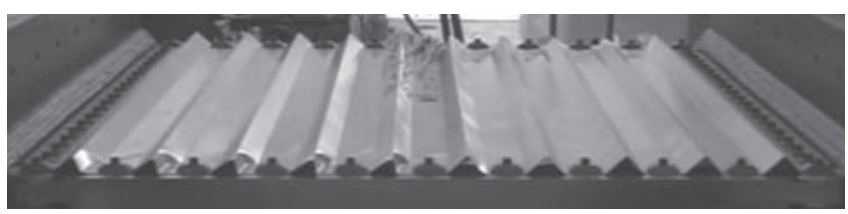

(a）断面のゆがみを伴わないウェブ座屈

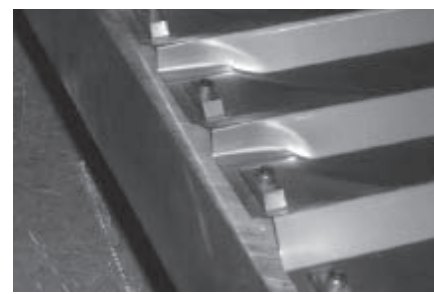

(b) ウェブ座屈の状況

写真 2 実験観察（t04-h20-f0）

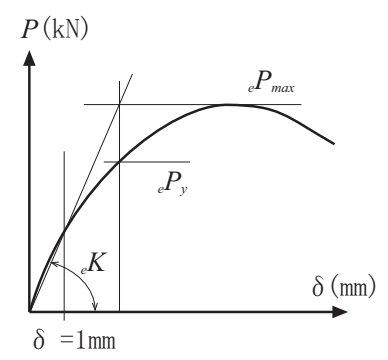

図 7 実験值の定義

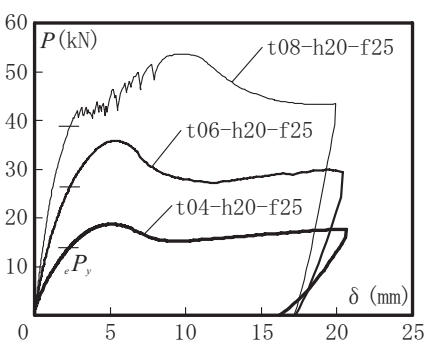

(c) 板厚 $t$ の影響
表 3 実験值

\begin{tabular}{|c|c|c|c|c|}
\hline & 試験体 & $\begin{array}{c}\underset{e}{e} K \\
(\mathrm{kN} / \mathrm{mm})\end{array}$ & $\begin{array}{l}e P_{y} \\
(\mathrm{kN})\end{array}$ & $\begin{array}{c}{ }_{e} P_{\max } \\
(\mathrm{kN})\end{array}$ \\
\hline & t04-h20-f40 & 3.93 & \begin{tabular}{|l|}
9.1 \\
\end{tabular} & 13.1 \\
\hline & t04-h20-f25 & 8.17 & 13.9 & 18.7 \\
\hline & t04-h20-f15 & 12.4 & 21. & 25.5 \\
\hline & t04-h20-f0 & 16.2 & 28.2 & 29.2 \\
\hline & t04-h30-f25 & 4.42 & 10.0 & 14.3 \\
\hline & t04-h40-f25 & 3.14 & 7.5 & 10.9 \\
\hline & t06-h20-f25 & 15.1 & 26.4 & 35.8 \\
\hline & t08-h20-f25 & 23.1 & 38.8 & 53.7 \\
\hline & t04-h20-f32 & 7.27 & 13.2 & 18.8 \\
\hline & t04-h20-f32J & 4.47 & 12.7 & 18.4 \\
\hline
\end{tabular}

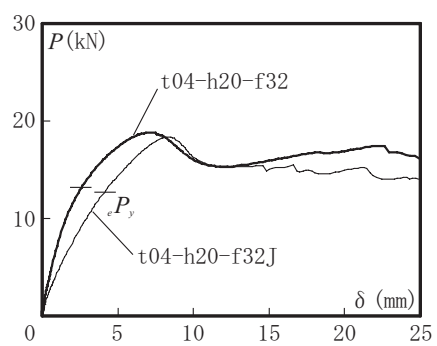

（d）接合金物の長さ $j$ の影響

図 8 せん断力 $P-$ せん断変形 $\delta$ 関倸 
ェブが座屈するという現象が観察され, 線形的に耐力上昇していく 過程で急激に荷重低下寸るという性状を示した，なお， ウェブが座 屈した後は, 前述の断面を長方形または台形とした試験体と同様の 変形挙動を示した。

図 8 に示すせん断力 $P-$ せん断変形 $\delta$ 関係においては, 初期剛性, 降伏耐力, 最大耐力, 最大耐力後の荷重低下の程度に, 実験変数の 影響による明瞭な差異が見られた。なお，最も高い荷重まで達した 板厚 $t=0.8 \mathrm{~mm}$ とした試験体（t08-h20-f25）では， $P=40 \mathrm{kN}$ を超えた近 傍で荷重に増減が見られるが, これはパネル周囲のボルト摩擦接合 部に滑りが発生したことによる. 表 3 に示す実験值、図 8 のせん断 力 $P$ - せん断変形 $\delta$ 関係 (図中に降伏耐力実験值 $P_{y}$ を変形軸に平行 な線分で表記）からは, 以下のような実験変数の影響が確認された. (a) 上フランジ幅の影響： 上フランジ幅 $f$ が小さくなるほど, 載荷 初期の剛性が高くなる. 降伏耐力および最大耐力は, $f$ が小さくな るほど上昇する傾向を示しているが，fの幅が著しく小さくなった $15 \mathrm{~mm}$ と $0 \mathrm{~mm}$ のケースでは最大耐力の差異は比較的小さい, また, 最 大耐力到達時の変形量は, 耐力が高いほど小さくなる傾向を示して いる. 最大耐力後の耐力劣化の程度は, 耐力上昇した試験体ほど急 激に耐力劣化する傾向を示している。

（b）高さの影響： 高さ $h$ が大きくなるほど, 載荷初期の剛性が低 くなる. 降伏耐力および最大耐力も同様に $h$ が大きくなるほど低下 する傾向を示している. また, 最大耐力が低いほど最大耐力到達時 の変形量は大きくなる傾向を示し, 耐力劣化の程度は最大耐力が小 さい試験体ほど緩やかになっている。

(c) 板厚の影響 : 板厚 $t$ が大きいほど, 載荷初期の剛性が高く, 降 伏耐力および最大耐力ともに大きくなる. ボルト接合部に滑りが生 じた t08-h20-f25 を除き, t04-h20-f25 と t06-h20-f25 のせん断力 $P-$ せん断変形 $\delta$ 関係は荷重方向に対して概ね相似形と捉えること ができ, 最大耐力到達時の変形や耐力劣化域の変形は同程度の值と なっている.

（d）接合金物の長さの影響： 下フランジを押さえる接合金物の長 さjが大きいほど載荷初期の剛性が高い, 一方, 降伏耐力および最 大耐力については，接合金物の長さの影響は小さく $\mathrm{t} 04-\mathrm{h} 20-\mathrm{f} 32 （ j$ =28mm） と t04-h20-f32（ $j=12 \mathrm{~mm} ）$ で明瞭な差異はみられない.

\section{4. 端部崩壊挙動に対する剛性および耐力の評価}

\section{1 剛性式の導出}

波形鋼板の幾何学的な特徵を考慮した面内せん断岡性の評価方法 として，面内せん断力により生じる波形鋼板の弾性ひずみエネルギ

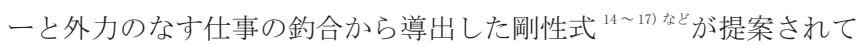
いる. ここでは, 剛性式の導出に用いる変形モデルを耐力式導出で 仮定する塑性崩壊モデルに展開すること意図し, 文献 14 に示される 長方形断面の波形鋼板を対象とした剛性式を，本試験で対象とする 台形断面の波形鋼板にも対応するように拡張した岡性式を改めて提 示する.

波形鋼板パネルが面内せん断力を受けると, 板要素の面内せん断 変形に加え, 山部の断面がゆがむ変形が生じ，見かけのせん断変形 が助長される. 文献 14 に基づき, ゆがみ变形を図 9 のようにモデル 化する.図 9 (a) において, 波形鋼板の断面は山部の長手方向におい て逆対称に線形的に変化するものと仮定する. 既往の研究 ${ }^{15 \sim 17)}$ には,

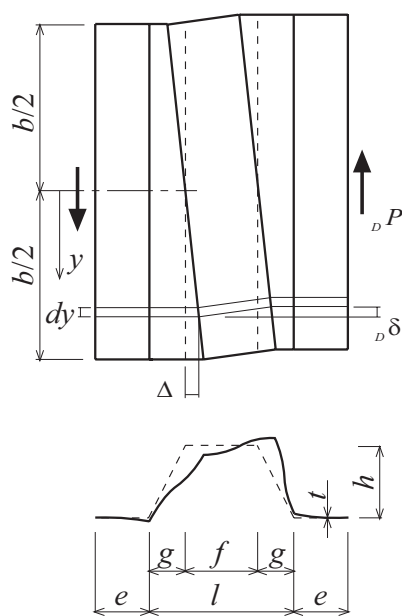

(a) 断面のゆがみ

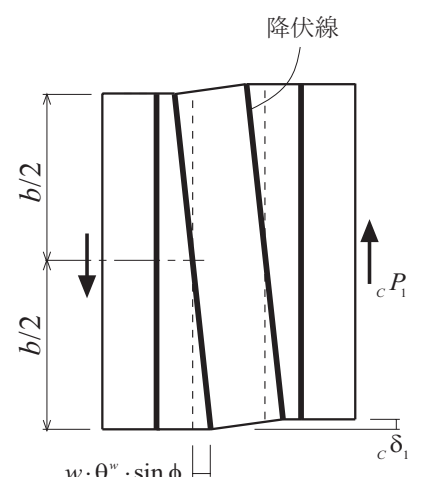

$w \cdot \theta_{1}^{w} \cdot \sin \phi$

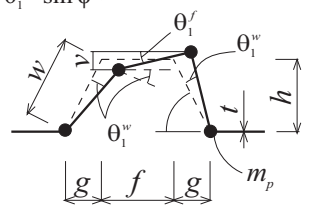

図 10 塑性崩壊モデル

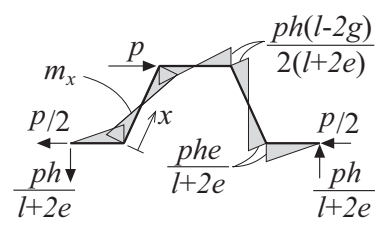

(b) 曲げモーメント

図 9 変形モデル

稜線は線形ではなく曲げ変形を伴うとして扱うものもあるが, 写真 1 (b) に示寸実験観察された稜線の変形状況, 山ピッチ $q$ に対する山 の長さ $b$ の比が 10 倍程度であれば稜線の曲げの影響は比較的小さい ことを示寸既往知見 ${ }^{15)}$ を参考に, 本研究では稜線の曲げ変形を考慮 しない変形モデルを採用した，なお，接合金物と鋼製枠に挟まれる 接合部近傍の下フランジの変形は拘束されるが，剛性式の導出にお いては, 図 9 (a) に示寸変形図のように, 下フランジの変形は許容さ れるものとして扱った。

図 9 に示寸一山分の波形鋼板パネルを対象に, 外力 ${ }_{D} P$ とせん断変 形 ${ }_{D} \delta$ とから定まる外部仕事 ${ }_{D} U_{e}$ と, パネルがな寸内部仕事 ${ }_{D} U_{i}$ の釣 合から剛性式を導く，図 9 (a) に示寸ように, 変形モデルでは上フラ ンジとウェブの面がねじれる変形を伴うが，この変形によるひずみ

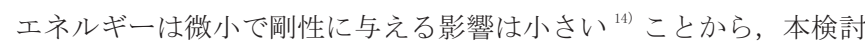
では考慮しないこととした。

ゆがみ変形により波形鋼板パネルがなす内部仕事 ${ }_{D} U_{i}$ は, 図 $9(\mathrm{~b})$ に示寸山部長手方向に対する単位幅 $d y$ 当たりの断面をゆがめるよう に作用する仮想力 $p$ によるモーメント $m_{x}$ がな寸仕事を, 山部の長手 方向に積分して算出する．単位幅あたりの内部仕事 ${ }_{D} u_{i}$ は，ヤング係 数 $E$, 板の曲げ剛性 $I$ を用いて次式で与えられる.

$$
{ }_{D} u_{i}=\int \frac{m_{x}^{2}}{2 E \cdot I} d x
$$

ここで, I は単位幅 $d y$ あたりの板の曲げ剛性で次式で与える.

$$
I=\frac{d y \cdot t^{3}}{12}
$$

図 9 (b) に示寸曲げモーメント分布に基づき，各辺における端点から 
の距離 $x$ の位置における曲げモーメント $m_{x}$ を定めて式 (6) に代入す ると, 内部仕事 ${ }_{D} u_{i}$ が次式として得られる.

$$
\begin{aligned}
{ }_{D} u_{i}= & \frac{1}{2 E \cdot I}\left\{2 \int\left(\frac{p h}{l+2 e} x\right)^{2} d x+2 \int\left(-\frac{p h e}{l+2 e}+\frac{p h(2 e+f)}{2(l+2 e) w} x\right)^{2} d x\right\} \\
& +\frac{1}{2 E \cdot I}\left\{\int\left(\frac{p h f}{2(l+2 e)}-\frac{p h}{l+2 e} x\right)^{2} d x\right\} \\
= & \frac{p^{2} \cdot h^{3} \cdot D}{2 E \cdot I} \\
D= & \frac{8 e^{3}+8 e^{2} \cdot w-4 e \cdot f \cdot w+2 f^{2} \cdot w+f^{3}}{12 h(l+2 e)^{2}}
\end{aligned}
$$$$
\cdots(9)
$$

一方, 仮想力 $\mathrm{p}$ がな寸外部仕事 ${ }_{D} u_{e}$ は次式で与えられる.

$$
{ }_{D} u_{e}=p \cdot \Delta / 2
$$$$
\text { .................... (10) }
$$

${ }_{D} u_{i}$ と ${ }_{D} u_{e}$ の釣合から次式が得られる.

$$
p=\frac{E \cdot I}{D \cdot h^{3}} \Delta
$$

また, 図 9a の変形モデルにおける幾何学的な関係から, $\Delta$ と ${ }_{D} \delta$ の 関係式が以下のように定まる。

$$
\Delta=\frac{{ }_{D} \delta}{f} y
$$

式 (6), 式 (8), 式 (11), 式 (12) から, 山部の長手方向全体に渡る 内部仕事 $U_{D}$ が得られる.

$$
{ }_{D} U_{i}=\sum_{D} u_{i}=\int_{\frac{b}{2}}^{\frac{b}{2}} \frac{E \cdot t^{3}}{24 D \cdot h^{3}}\left(\frac{{ }_{D} \delta}{f} y\right)^{2} d y=\frac{E \cdot t^{3} \cdot b^{3} \cdot{ }_{D} \delta^{2}}{288 D \cdot h^{3} \cdot f^{2}}
$$

また，外部仕事 ${ }_{D} U_{e}$ は次式で与えられる.

$$
{ }_{D} U_{e}={ }_{D} P \cdot{ }_{D} \delta / 2
$$

${ }_{D} U_{e}$ と ${ }_{D} U_{i}$ の釣合から, 外力 ${ }_{D} P$ とせん断変形 ${ }_{D} \delta$ の関係を求め整理寸 ると, 断面のゆがみにより生じるせん断方向の変形に対する剛性 ${ }_{D} K$ が次式で与えられる.

$$
{ }_{D} K=\frac{{ }_{D} P}{{ }_{D} \delta}=\frac{E \cdot t^{3} \cdot b^{3}}{144 D \cdot h^{3} \cdot f^{2}}
$$

一方，板要素の面内せん断変形に対する剛性は，波形鋼板の展開長 を考慮したせん断剛性 ${ }_{s} K$ として, ポアソン比 vを用いて次式で与 えられる。

$$
{ }_{s} K=\frac{b \cdot t \cdot E}{2(f+2 w+2 e)(1+v)}
$$

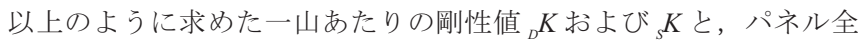
体での山数 $n$ を用いて, せん断力を受ける波形鋼板パネルのせん断 剛性 $C^{K}$ の評価式が得られる.

$$
{ }_{c} K=\left(\frac{1}{{ }_{D} K}+\frac{1}{{ }_{s} K}\right)^{-1} \frac{1}{n}
$$

\section{2 耐力式の導出}

面内せん断試験では，断面を三角形とした t04-h20-f0 を除く全て の試験体において, パネル端部の断面が倒れ込みながら塑性崩壊す る図 1 (b) のスウェイと同様の現象が観察された。この崩壊機構に着 目し, 剛性式の導出に用いた図 9 の変形モデルを図 10 に示寸塑性崩 壊モデルに拡張することで耐力式の導出を試みる。

図 10 の塑性崩壊モデルは, 図 9b に示す断面各辺の曲げモーメン トが最大となる波形鋼板の稜線部に直線の降伏線ヒンジを仮定する ことで, 山部の長手方向の両端で逆対称に断面が倒れこむ三次元的

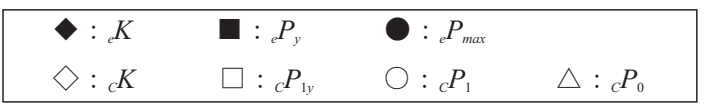

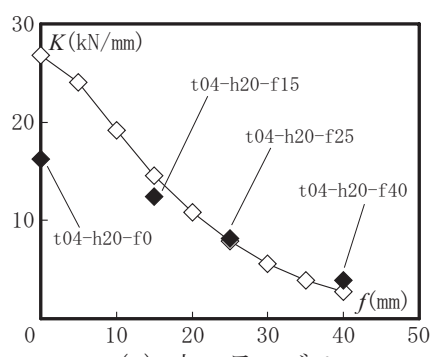

(a) 上フランジ $f$

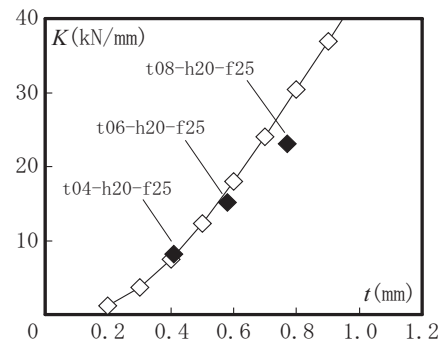

(b) 板厚 $t$

\begin{tabular}{|c|c|c|c|c|c|c|c|c|c|c|c|c|c|}
\hline & \multirow[b]{2}{*}{ 試験体 } & \multicolumn{3}{|c|}{ 実験值 } & \multicolumn{4}{|c|}{ 計算值 } & \multicolumn{5}{|c|}{ 実験值/計算值 } \\
\hline & & $\begin{array}{c}e^{K} \\
(\mathrm{kN} / \mathrm{mm})\end{array}$ & $\begin{array}{l}e P_{y} \\
(\mathrm{kN}) \\
\end{array}$ & $\begin{array}{c}e P_{\max } \\
(\mathrm{kN})\end{array}$ & $\begin{array}{c}{ }_{c} K \\
(\mathrm{kN} / \mathrm{mm})\end{array}$ & $\begin{array}{c}{ }_{c} P_{1 y} \\
(\mathrm{kN})\end{array}$ & $\begin{array}{l}{ }_{c} P_{1} \\
(\mathrm{kN})\end{array}$ & $\begin{array}{l}{ }_{c} P_{0} \\
(\mathrm{kN})\end{array}$ & $\frac{{ }_{e} K}{{ }_{c} K}$ & $\frac{{ }_{e} P_{y}}{{ }_{c} P_{1 y}}$ & $\frac{{ }_{e} P_{y}}{{ }_{c} P_{0}}$ & $\frac{{ }_{e} P_{\max }}{{ }_{c} P_{1}}$ & $\frac{{ }_{e} P_{\max }}{{ }_{c} P_{0}}$ \\
\hline \multirow{8}{*}{ I } & t04-h20-f40 & 3.93 & 9.1 & 13.1 & 2.74 & 5.98 & 8.98 & 5.64 & 1.43 & 1.52 & 1.62 & 1.46 & 2.32 \\
\hline & t04-h20-f25 & 8.17 & 13.9 & 18.7 & 7.86 & 12.4 & 18.7 & 5.64 & 1.04 & 1.11 & 2.45 & 1.00 & 3.31 \\
\hline & t04-h20-f15 & 12.4 & 21.9 & 25.5 & 14.6 & 29.3 & 43.9 & 5.64 & 0.85 & 0.75 & 3.88 & 0.58 & 4.51 \\
\hline & t04-h20-f0 & 16.2 & 28.2 & 29.2 & 26.8 & - & - & 5.64 & 0.61 & \begin{tabular}{|l|}
- \\
\end{tabular} & 5.00 & - & 5.18 \\
\hline & \begin{tabular}{|l|}
$\mathrm{t} 04-\mathrm{h} 30-\mathrm{f} 25$ \\
\end{tabular} & 4.42 & 10.0 & 14.3 & 3.63 & 8.3 & 12.4 & 5.64 & 1.22 & 1.20 & 1.77 & 1.15 & 2.53 \\
\hline & t04-h40-f25 & 3.14 & 7.5 & 10.9 & 1.92 & 6.22 & 9.34 & 5.64 & 1.64 & 1.21 & 1.33 & 1.17 & 1.93 \\
\hline & t06-h20-f25 & 15.1 & 26.4 & 35.8 & 16.8 & 25.8 & 38.8 & 9.85 & 0.90 & 1.02 & 2.68 & 0.92 & 3.63 \\
\hline & t08-h20-f25 & 23.1 & 38.8 & 53.7 & 28.5 & 41.3 & 61.9 & 13.7 & 0.81 & 0.94 & 2.84 & 0.87 & 3.93 \\
\hline & t04-h20-f32 & 7.27 & 13.2 & 18.8 & 6.34 & 9.78 & 14.7 & 5.64 & 1.15 & 1.35 & 2.33 & 1.28 & 3.34 \\
\hline & t04-h20-f32. & 4.47 & 12.7 & 18.4 & 6.34 & 9.78 & 14.7 & 5.64 & 0.71 & 1.30 & 2.25 & 1.25 & 3.26 \\
\hline
\end{tabular}

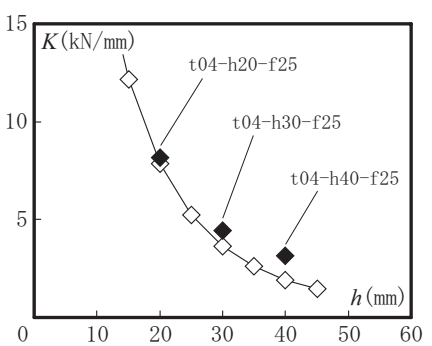

(c) 高さ $h$

図 11 実験剛性と剛性式の対応

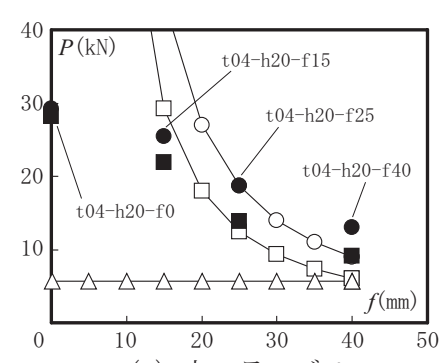

(a) 上フランジ $f$

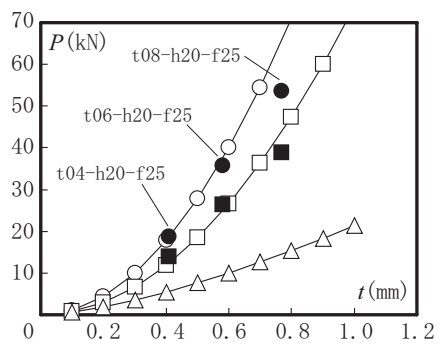

(b) 板厚 $t$

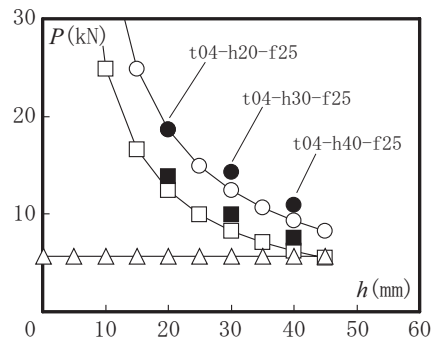

(c) 高さ $h$

図 12 実験耐力と耐力式の対応
表 4 実験值と計算值の対応

な崩壊モードを表現したものである. 幾何学的に上フランジとウェ ブの面は㸚じれることになるが，この面のねじれがな寸仕事は考慮 していない. また, 下フランジは幾何学的に変形しないものと仮定し, シリーズ II の試験体で設定した接合金物の寸法による下フランジの 固定幅の影響は特に考慮していない。 なお，図 10 のモデルと図 3 に 示寸既往研究 ${ }^{12)}$ のモデルでは，断面内の塑性ヒンジ形成位置に差異 が見られるが，この違いが耐力式に与える影響については付録にて 言及する.

極限解析の考えに基づき，波形鋼板パネルが完全塑性の材料特性 を持つものとみなし, 図 10 の崩壊機構において降伏線がなす内部仕 事の総和 ${ }_{C} U_{1 i}$ と, 外力 ${ }_{C} P_{1}$ がなす外部仕事 ${ }_{C} U_{1 e}$ の釣合から耐力式を導 
出する. 降伏線がな寸内部仕事 ${ }_{C} U_{1 i}$ は, 図 10 に示す塑性崩壊モデル に基づき, 山部の長手方向の両端部におけるウェブおよび上フラン ジのヒンジ回転角を $\theta_{1}^{w}$ および $\theta_{1}^{r}$ とし, 断面変形が生じない山部の長 手方向中央（写真 1 (b) の A-A' 部に相当）ではヒンジ回転角がゼロ となるよう山部の長手方向に沿って回転角が線形的に変化するとい う仮定から次式で与える.

$$
{ }_{C} U_{1 i}=m_{p}\left(4 \theta_{1}^{w}+2 \theta_{1}^{f}\right) \frac{b}{2}
$$

ここで, $m_{p}$ は山部長手方向に対する降伏線単位長さあたりの塑性モ 一メントであり, 素材降伏点 $\sigma_{y}$ と板厚 $t$ 用いて次式で与えられる.

$m_{p}=t^{2} \cdot \sigma_{y} / 4$

$\theta_{1}^{w}$ と $\theta_{1}^{r}$ は, ウェブと上フランジの交点となる上フランジ両端点の変 位差 $v$ に着目し，幾何学的な適合条件を考え次式で関連付ける。

$$
\begin{aligned}
& v=f \cdot \theta_{1}^{\prime}=2 w \cdot \theta_{1}^{w} \cdot \cos \phi \\
& \text { …... (20) } \\
& \theta_{1}^{f}=\frac{2 w}{f} \cdot \cos \phi \cdot \theta_{1}^{w}
\end{aligned}
$$

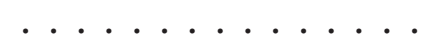

式（21）および式（18）から， $U_{1 i}$ は $\theta_{1}^{w}$ を用いて次式で表される.

$$
{ }_{c} U_{1 i}=4 m_{p}\left(1+\frac{w}{f} \cos \varphi\right) \theta_{1}^{w} \cdot \frac{b}{2}
$$

また, せん断変形 ${ }_{c} \delta_{1}$ とヒンジ回転量 $\theta_{1}^{w}$ の関係は, 上フランジが剛 体回転した場合の幾何学的な条件から次式で与えられる.

$$
{ }_{c} \delta_{1}=2 f \cdot w \cdot \theta_{1}^{w} \cdot \sin \phi / b
$$

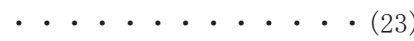

外力 ${ }_{c} P_{1}$ と変形量 ${ }_{c} \delta_{1}$ の積である外部仕事 ${ }_{c} U_{1 e}$ は次式で表される

$$
{ }_{C} U_{1 e}={ }_{C} P_{1} \cdot{ }_{C} \delta_{1}=2 f \cdot w \cdot \theta_{1}^{w} \cdot \sin \phi / b \cdot{ }_{C} P_{1}
$$

よって, 外部仕事 ${ }_{C} U_{1 e}$ と内部仕事 ${ }_{C} U_{1 i}$ の釣合から, 端部崩壊挙動に 対する耐力 $P_{1}$ は以下のように導出される.

$$
{ }_{C} P_{1}=\frac{b^{2}}{f \cdot w \cdot \sin \varphi}\left(1+\frac{w}{f} \cos \varphi\right) m_{p}
$$

以上の塑性崩壊モデルに基づく耐力式は最大耐力を想定したもので あるが，降伏耐力を想定した耐力 $c_{1 y}$ を式 (25) 中の塑性モーメント $m_{p}$ を降伏モーメント $m_{y}$ に置き換えて次式で与えるものとする.

$$
\begin{gathered}
{ }_{c} P_{1 y}=\frac{b^{2}}{f \cdot w \cdot \sin \varphi}\left(1+\frac{w}{f} \cos \varphi\right) m_{y} \\
\ldots \ldots \ldots(26)
\end{gathered}
$$

なお，式 (25) および式（26）は，上フランジ幅 $f$ をゼロとした場合 に解を得ることができなくなるが，これは式 (21) に示す $\theta_{1}^{w} と \theta_{1}^{r}$ の 幾何学的な関係が $f$ をゼロとした三角形状の断面では成立しないこ とに起因する。

\section{3 剛性式および耐力式と実験結果の対応}

図 7 に示寸定義に基づき定めた初期剛性実験值 $K$, 降伏耐力実験 值 $P_{y}$, 最大耐力実験值 $e_{\text {max }}$ と, 式 (17) による剛性計算值 ${ }_{c} K$, 式 （26）による降伏耐力計算值 ${ }_{C} P_{1 y}$, 式 (25) による最大耐力計算值 ${ }_{C} P_{1}$, また既往の式 (4) による耐力計算值 ${ }_{C} P_{0}$ との対応を表 4 に示す. 表 4 の結果に基づき, シリーズ I の試験体の初期剛性, 降伏耐力, 最大 耐力の評価結果を, 図 11 および図 12 に示すように実験変数毎にま とめた。 図 11 中の黒菱形（〉） は初期剛性実験值 $K$, 白菱形 $(\diamond)$ は式 (17) による剛性計算值 ${ }_{C} K$ を表す. 図 12 中の黒（口）は降伏耐 力実験值 $P_{y}$, 黒丸 $(\mathbf{O})$ は最大耐力実験值 $P_{\text {max }}$, 白四角 $(\square)$ は式
（26）による降伏耐力計算値 ${ }_{c} P_{1 y}$, 白丸（○）は式 (25) による最大耐 力計算值 ${ }_{c} P_{1}$, 白三角 $(\triangle)$ は式 (4) において $k_{\mathrm{m}}=0.9^{9)}$ として算出し た耐力計算值 $P_{0}$ を表す.

図 11 に示寸実験剛性と剛性式の対応において, 上フランジ幅 $f$ を ゼロとした断面形状の試験体（t04-h20-f0）を除き，実験変数が変 化しても剛性計算値 ${ }_{c} K$ は初期剛性実験值 $K$ と 良好に対応している. これより, 今回の試験範囲（山ピッチ $q$ に対する山の長さ $b$ の比が 約 10 倍）程度のパネル形状であれば，稜線の曲げ変形を考慮しない 変形モデル（図 9）に基づく剛性式でも概放妥当な剛性評価結果が 得られることが分かる.

また，図 12 に示す実験耐力と耐力式の対応から，既往知見による 耐力計算值 $P_{0}(\triangle)$ は実験変数に対する感度は低く, 断面の形状変 化が耐力に与える影響を十分に表現できていないことが分かる．ま た， $P_{0}$ は最大耐力のみならず降伏耐力に対してもパネル形状によっ ては実験值に対し著しく過小な評価を与える傾向がある。これに対 し, 図 10 の塑性崩壊モデルに基づく耐力式は, 降伏耐力計算值 ${ }_{c} P_{1 y}$ （口）および最大耐力計算值 $P_{1}(\bigcirc)$ ともに，実験変数に対する感 度に改善が見られるとともに, 上フランジ幅 $f$ がさい試験体（t04h20-f15，t04-h20-f0）およびパネル周囲のボルト接合部に滑りが生 じた試験体（t08-h20-f25）を除き，それぞれ降伏耐力実験值 $P_{\mathrm{y}}$ お よび最大耐力実験值 $P_{e}$ max と良好に対応している.

シリーズII の試験体については，表４に示すように下フランジを 押さえる接合金物の長さ $j$ が小さい t $04-h 20-f 32 J$ で初期剛性実験值 ${ }_{e} K$ が若干低下寸る傾向を示しているが，剛性計算值 ${ }_{C} K$ および耐力計 算值 ${ }_{c} P_{1 y}, c_{1}$ は実験結果に対し概ね妥当な評価結果を与えている.

上フランジ幅 $f$ に関する評価精度は, 式 (17) の剛性計算值 ${ }_{c} K$, 式 （26）および式（25）の耐力計算值 $c_{c} P_{1 y}, c_{c} P_{1}$ において, $f$ がゼロに近 づくにつれ低下寸る傾向を示している，これは，断面が三角形に近 づくにつれ, 図 9 の変形モデルおよび図 10 の塑性崩壊モデルに示す ような曲げ支配型の抵抗機構ではなくなり，トラスの作用（ウェブ が面内の軸力で抵抗）が強まることに起因するものであると推察す る.これらの抵抗機構が連成した場合の評価精度の向上は今後の課 題である.

\section{5. まとめ}

本研究では, 波形鋼板パネルの断面形状や板厚が端部崩壊挙動の 力学特性に与える影響を面内せん断試験により確認するとともに, 実験観察された破壊形態を参考に三次元的な変形を考慮した塑性崩 壊モデルを仮定し，極限解析の適用により耐力式の提案を試みた。

波形鋼板の端部崩壊挙動における剛性および而力は，上フランジ 幅が小さく，山高さが低く，板厚が大きいほど向上する．また，破 壊形態としては，台形や長方形の断面形状とした場合には，波形鋼 板の山部が稯線をほぼ線形に保ちながら長手方向中央に対して両端 の断面が逆対称に倒れこむという性状を示し，三角形断面の場合で は，断面がゆがむ変形をほとんど生じないまま圧縮力を負担する側 のウェブが座屈するという性状を示した.

既往のせん断剛性式で仮定する弾性変形モデルの拡張により，実 験観察された破壊形態に対応寸る塑性崩壊モデルを仮定し，モデル 中の降伏線ヒンジがなす内部仕事と外力仕事の釣合から耐力式を導 出した，提案耐力式は，上フランジ，山高さ，板厚といった波形鋼 
板の断面形状の変化の影響を表現可能なものであり，降伏耐力およ び最大耐力について実験值と良好な対応を示した。 また，既往知見 に基づき導出したせん断岡性式についても, 初期剛性実験值と妥当 に対応することが確認された.

なお，上フランジ幅が小さくなり，板要素の面外の曲げが支配す る抵抗機構から, 板要素の面内の軸力が支配するトラス型の抵抗機 構に移行した場合の剛性および而力の評価精度向上については，今 後の課題である.

\section{付録}

図 3 (c) と図 10 の断面内における塑性ヒンジ形成位置の違いが耐力に与える 影響を確認寸るため, 本研究の手法に做い, 図 $3\left(\right.$ (c) の機構 ${ }^{(2)}$ を山部長手方向 一拡張した付図 1 の塑性崩壊モデルを仮定し, ここから導出される耐力式と式 （25）の比較を試みる。

付図 1 の崩壊機構がな寸内部仕事 $U_{2}$ は, 山部の長手方向の両端部における ウェブおよび下フランジのヒンジ回転角を $\theta_{1}$ および $\theta_{2}$, 降伏線単位長さあた りの塑性モーメントを $m$ とし，山部の長手方向中央ではヒンジ回転角がゼロ となるように回転角が線形的に変化する，との仮定に基づき次式で与える。

$$
{ }_{c} U_{2 i}=2 m_{p}\left(\theta_{1}+\theta_{2}\right) \frac{b}{2}=2 m_{p} \frac{q-e}{e} \theta_{1} \frac{b}{2} \quad \ldots \ldots \ldots \text { 付 (1) }
$$

また，せん断変形 $\delta_{2}$ とヒンジ回転量 $\theta_{1}$ の関係は，上フランジが剛体回転した 場合の幾何学的な条件から次式で与えられる。

$$
{ }_{c} \delta_{2}=2 / b \cdot f \cdot h \cdot \theta_{1} \quad \ldots \ldots \ldots \text { 付 (2) }
$$

外力 $P_{2}$ と変形量 ${ }_{C} \delta_{2}$ の積である外部仕事 ${ }_{C} U_{2 e}$ は次式で表される.

$$
{ }_{C} U_{2 e}={ }_{c} P_{2} \cdot{ }_{c} \delta_{2}=\frac{2 f \cdot h}{b} \theta_{1} \cdot{ }_{c} P_{2} \quad \ldots \ldots \ldots \text { 付 (3) }
$$

外部仕事 ${ }_{C} U_{2 e}$ と内部仕事 ${ } U_{2 i}$ の釣合から，付図 1 の塑性崩壊モデルの仮定に基 づく耐力 $P_{2}$ が以下のように導出される.

$$
{ }_{c} P_{2}=\frac{b^{2}(q-e)}{2 f \cdot h \cdot e} m_{p} \quad \ldots \ldots \ldots \text { 付 (4) }
$$

式 (25) と付式 (4) および実験最大耐力 $P_{\text {max }}$ の対応を付図 2 に示す。付式 (4) は上フランジ幅 $f$, 板厚 $t$, 山高さ $h$ に対して式 (25) と概丞同等の感度と 評価精度を有していることが分かる。このことから，断面内における塑性ヒン ジ形成位置の差異より，山部長手方向に対する崩壊機構の拡がりの扱いの差異 が，既往研究 ${ }^{12)}$ と本研究の耐力式が与える解の差の要因になっているものと 推察する。

\section{参考文献}

1）波形鋼板ウェブ PC 橋計画マニュアル(案), 波形鋼板ウェブ合成構造研究会, 1998. 12

2) 山崎正直：波形鋼板ウェブの座屈耐荷力，日本土木学会構造工学論文集, Vol. 47A, pp. 19-26, 2001.3

3) 麻生直木 他 : 波形鋼板耐震壁の力学性状に関する研究（その $1 \sim 2$ ), 日 本建築学会大会学術講演梗概集，C-1, pp. 1123-1126, 2006.9

4）池田崇 他：波形鋼板耐震壁の力学性状に関する研究（その $3 \sim 5$ ), 日本 建築学会大会学術講演梗概集, C-1, pp. 1121-1126, 2007. 8

5）富岡義人，五十嵐規矩夫 他：薄板鉄鋼材料を用いた鋼構造建築物の 能性の探求と開発（その $1 \sim 7)$, 日本建築学会大会学術講演梗概集, A-1, pp. 971-984, 2007. 8

6）五十嵐規矩夫，藤澤逸志，清水信孝：矩形形状を有する波形鋼板の也 儿断弾性座屈耐力評価, 日本建築学会構造系論文集, 第 73 巻, N0.632, pp. 1883-1890, 2008. 10

7)A.H.Nilson: Shear Diaphragms of Light Gage Steel, Proc.A.S.C.E., J. Struc. Div. , pp. 111-139， 1960. 11

8) Diaphragm Design Manual Third Edition, Steel Deck Institute, 2004. 9

9) European Recommendations for the Application of Metal Sheeting acting as a Diaphragm, European Convention for Construction Steelwork, 1995

10) J.M. Davies, E.R.Bryan : Manual of Stressed Skin Diaphragm Design, 1982

11) J. T. Easlay: Buckling Formulas for Corrugated Metal Shear Diaphragm, Proc. A. S. C.E., J. Struc. Div., pp. 1403-1417, 1975.7

12) J.M. Davies, J.Fisher: End failure in stressed skin diaphragms, Proc. Instn Civ. Engrs, Part2, pp. 275-293, 1987.3

13）鋼構造座屈設計指針、日本建築学会、pp. 197-200、1996.

14)E. R. Bryan, P. Jackson: The Shear Behavior of Corrugated Steel Sheeting, Thin walled Steel Structures Their Design and Use in Building, pp. 258-274, 1967.9

15) J.M. Davies, R.M. Lawson: The Shear Deformation of Profiled Metal Sheeting, International Journal for Methods in Engineering, Vol. 12, pp. 1507-1541, 1978

16) J. M. Davies: A General Solution for the Shear Flexibility of Profiled Sheets. I-II, Thin-Walled Structures 4, pp. 41-68, 141-161, 1986

17) 原田昌利：デッキプレート部材の面内剪断岡性解析, 鋼構造年次論文報告 集，第 15 巻，pp. 519-526, 2007. 11

18）鋼構造建築物の構造性能評価試験法に関する研究委員会報告書, 独立行政法人建築研究所, 社団法人日本鉄鋼連盟, pp. 81-87, 2002.4

19）床鋼板構造設計施工規準・同解説，日本鋼構造協会社団法人日本鉄鋼連盟, pp. $82-85,1972.7$
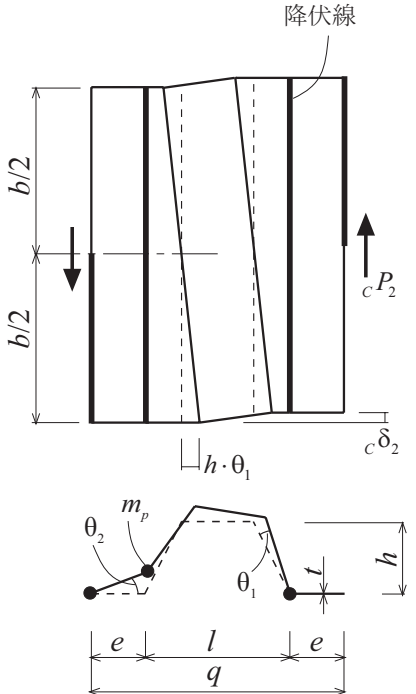

付図 1 図 3(c) の拡張モデル

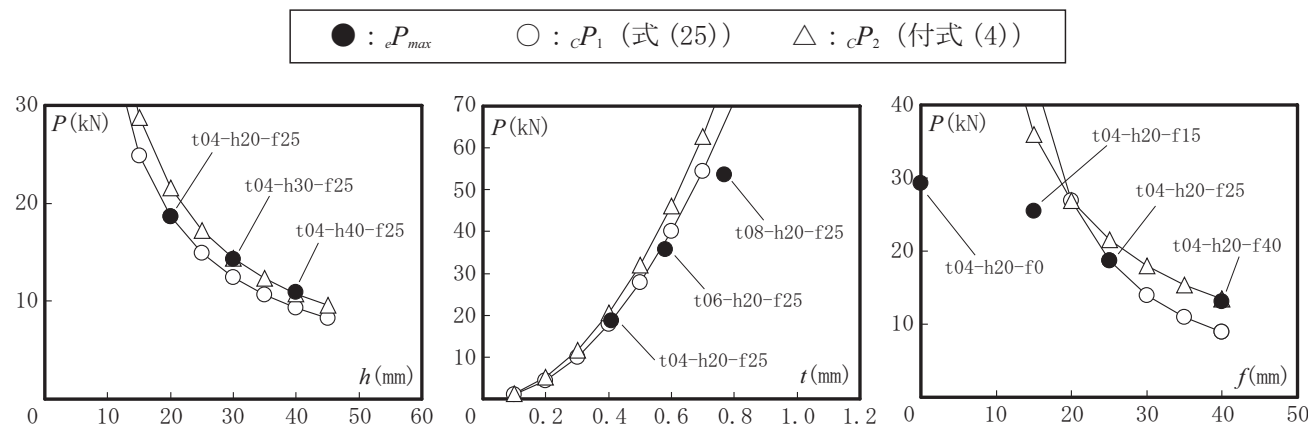

(c) 高さ $h$

(a) 上フランジ $f$

付図 2 式 (25) と付式 (4) および $P_{e}$ 而 の対応 